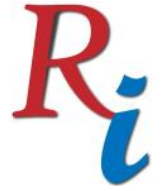

Asia Proceedings of Social Sciences

(APSS)

www.readersinsight.net/APSS

\title{
Review on Gender Difference in HSB and PTG after Natural Disaster
}

\author{
Sadaf Alamdar \\ Institute of Psychology, Chinese Academy of Sciences \\ China

\section{Yuqing Zhang} \\ Institute of Psychology, Chinese Academy of Sciences \\ China
}

*Corrosponding author's Email: skalamdar@hotmail.com

Peer-review under responsibility of $4^{\text {th }}$ Asia International Conference 2018 editorial board (http://www.utm.my/asia/our-team/)

(C) 2018 Published by Readers Insight Publisher, lat 306 Savoy Residencia, Block 3 F11/1,44000 Islamabad. Pakistan, info@ readersinsight.net

This is an open access article under the CC BY-NC-ND license (http://creativecommons.org/licenses/by-nc-nd/4.0/). 


\section{Rese a r ch High Iights}

Survivors of natural disasters not only experience distress but also growth which is known as Post traumatic growth. Total 10 studies which were done on HSB and PTG and assessed the role of gender in natural disaster were included. Being younger, female, education, socioeconomic class, exposure and coping strategies linked with HSB and PTG

\section{Research Objectives}

Millions of people are affected by the natural disasters in different regions of world. Survivors often witnesses prolong psychological distress by the death of loved one, damage of property, injuries and shortage of basic need. However, individual differences occur in their struggle with trauma, they also manifest positive change which is known as Post traumatic growth (Kleim \& Ehlers, 2009). This growth can occur in both male and female survivors, findings of researches are inconsistent.

Help seeking behaviour refers to person's communication to seek guidance and support for treatment either formally from the professionals or informally. Researches on HSB show few trends. Young people and female seek help informally before they ask for the formal help whereas male try to avoid seek help at first (Benson, 1990; Offer, Howard, Schonert, \& Ostrov, 1991; Rickwood \& Braithwaite, 1994).

As per authors knowledge there is no published study available on gender role in help seeking behavior and PTG in natural disaster. The purpose to conduct this review article is to fill this gap in the literature. Furthermore, this will determine a role gender can play when seeking help and developing PTG and will help professionals to make treatment plans for different genders according to their needs.

\section{Methodology}

The studies which were included in the article were published from 2000 to 2016. Studies that were done on adult population were included whereas studies done on children and adolescence were excluded. For assessing gender difference the criteria was natural disaster. 


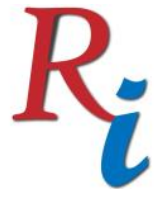

\section{Asia Proceedings of Social Sciences \\ (APSS) \\ www.readersinsight.net/APSS}

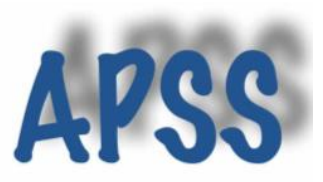

Studies that were done on PTG and HSB without assessing gender difference and were not done in natural disaster were excluded from the review. For reviewing the literature Google scholar, NCBI and Psych info was used. Keywords of Post traumatic growth, Natural disaster, Gender differences and Help seeking behavior were used to identify the relevant literature. Only Primary studies were included and total 10 studies met the criteria.

\section{Results}

Results of PTG and gender differences were inconsistent. Out of nine studies three studies showed the significant gender difference (Fergusson, Boden, Horwood, \& Mulder, 2015; Jin, Xu, \& Liu, 2014; Xu \& Liao, 2011), five studies demonstrate no gender difference (Aslam \& Kamal, 2015; Bianchini et al., 2017; García, Páez-Rovira, Zurtia, Martel, \& Reyes, 2014; Mordeno, Nalipay, Alfonso, \& Cue, 2016; Siqveland, Nygaard, Hussain, Tedeschi, \& Heir, 2015) Only one study demonstrate the more prevalence of PTG in male ( $\mathrm{Wu}$, Zhang, Liu, Zhou, \& Wei, 2015). Being younger and with higher education were the two significant demographic variables for the PTG (Aslam \& Kamal, 2015; Fergusson et al., 2015). Only one study on HSB met the criteria which were done after the Miyake island volcanic eruption. Being younger and female related with more help from informal sources, whereas being male and older related with more help from professionals. Widows and single seek more help from Primary care married couples (Goto, Kahana, Wilson, \& Slane, 2002).

\section{Findings}

Although there were no study published which directly assess the relationship between HSB, PTG and gender difference, by critically reviewing the studies it is shown help seeking behavior differs in different genders which lead to the PTG in natural disasters. The results are inconsistent because of the different methodology used to assess the differences. However, being young, female gender, education, disaster exposure, socioeconomic status and use of different coping strategies lead to seek more help and the development of PTG. Longitudinal studies and inclusion of interview method with the survey will explore the participant's responses on the questionnaire. 


\section{References}

Aslam, N., \& Kamal, A. (2015). Coping Strategies as a Predictors of Psychological Distress and Post Traumatic Growth among Flood Affected Individuals. Journal of Alcoholism \& Drug Dependence.

Benson, P. L. (1990). Help-seeking for alcohol and drug problems: To whom do adolescents turn? Journal of Child \& Adolescent Substance Abuse, 1(1), 83-94.

Bianchini, V., Giusti, L., Salza, A., Cofini, V., Cifone, M., Casacchia, M., . . Roncone, R. (2017). Moderate Depression Promotes Posttraumatic Growth (Ptg): A Young Population Survey 2 Years after the 2009 L'Aquila Earthquake. Clinical practice and epidemiology in mental health: CP \& EMH, 13, 10.

Fergusson, D. M., Boden, J. M., Horwood, L. J., \& Mulder, R. T. (2015). Perceptions of distress and positive consequences following exposure to a major disaster amongst a well-studied cohort. Australian \& New Zealand Journal of Psychiatry, 49(4), 351-359.

García, F. E., Páez-Rovira, D., Zurtia, G. C., Martel, H. N., \& Reyes, A. R. (2014). Religious coping, social support and subjective severity as predictors of posttraumatic growth in people affected by the earthquake in Chile on 27/2/2010. Religions, 5(4), 1132-1145.

Goto, T., Kahana, B., Wilson, J., \& Slane, S. (2002). PTSD, depression and help-seeking patterns following the Miyake Island volcanic eruption. International Journal of Emergency Mental Health, 4(3), 157-172.

Jin, Y., Xu, J., \& Liu, D. (2014). The relationship between post traumatic stress disorder and post traumatic growth: gender differences in PTG and PTSD subgroups. Social psychiatry and psychiatric epidemiology, 49(12), 1903-1910.

Kleim, B., \& Ehlers, A. (2009). Evidence for a curvilinear relationship between posttraumatic growth and posttrauma depression and PTSD in assault survivors. Journal of traumatic stress, 22(1), 45-52.

Mordeno, I. G., Nalipay, M. J. N., Alfonso, M. K. S., \& Cue, M. P. (2016). Examining the latent structure of posttraumatic growth between male and female survivors in the immediate aftermath of a flash flood disaster. Current Psychology, 35(4), 587-594.

Offer, D., Howard, K. I., Schonert, K. A., \& Ostrov, E. (1991). To whom do adolescents turn for help? Differences between disturbed and nondisturbed adolescents. Journal of the American Academy of Child \& Adolescent Psychiatry, 30(4), 623-630.

Rickwood, D. J., \& Braithwaite, V. A. (1994). Social-psychological factors affecting helpseeking for emotional problems. Social science and medicine, 39(4), 563-572.

Siqveland, J., Nygaard, E., Hussain, A., Tedeschi, R. G., \& Heir, T. (2015). Posttraumatic growth, depression and posttraumatic stress in relation to quality of life in 


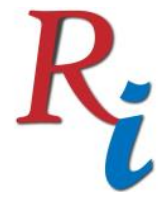

\section{Asia Proceedings of Social Sciences}

(APSS)

www.readersinsight.net/APSS

tsunami survivors: a longitudinal study. Health and quality of life outcomes, 13(1), 18.

Wu, K., Zhang, Y., Liu, Z., Zhou, P., \& Wei, C. (2015). Coexistence and different determinants of posttraumatic stress disorder and posttraumatic growth among Chinese survivors after earthquake: role of resilience and rumination. Frontiers in psychology, 6, 1043.

Xu, J., \& Liao, Q. (2011). Prevalence and predictors of posttraumatic growth among adult survivors one year following 2008 Sichuan earthquake. Journal of affective disorders, 133(1), 274-280. 